\title{
Environment management and health risks of soil erosion gullies in São Luís (Brazil) and their potential remediation using palm-leaf geotextiles
}

\author{
A. Guerra ${ }^{1}$, M. Marcal ${ }^{1}$, H. Polivanov ${ }^{1}$, R. Sathler ${ }^{1}$, J. Mendonça ${ }^{1}$,

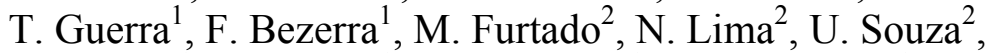 \\ A. Feitosa ${ }^{2}$, K. Davies ${ }^{3}$, M. A. Fullen ${ }^{3}$ \& C. A. Booth ${ }^{3}$ \\ ${ }^{1}$ Geography Department., Federal University of Rio de Janeiro, Brazil \\ ${ }^{2}$ Federal University of Maranhao, São Luís, Brazil \\ ${ }^{3}$ Research Institute in Advanced Technologies (RIATec), The University \\ of Wolverhampton, U.K.
}

\begin{abstract}
Urban soil gully erosion in São Luís, Brazil, has resulted in loss of lives and properties. Environmental conditions (soil properties/use, rain regime, slope characteristics) associated with deforestation, brought on by irregular, unplanned and unauthorized urban settlement expansion (without basic urban infrastructure, especially sanitation, rain pipes and paved roads), has promoted land degradation and initiated gully formation. Therefore, understanding the factors that generate erosive processes, as well as the application of control measures and prevention, are fundamental actions for public safety. A novel control approach is the application of palm-mat geotextiles. These offer considerable potential to contribute to soil conservation, through sustainable and environmentally friendly palm agriculture. Ongoing field and laboratory research, in Europe, South America, Africa and SE Asia, is investigating geotextile mats manufactured from palm-leaves to evaluate their long-term effectiveness in controlling soil erosion and to assess their sustainability and economic viability. Palm-leaf geotextiles are novel and offer new bioengineering solutions to environmental problems, as temporary application of geotextiles allows sufficient time for plant communities to stabilize engineered slopes. Initial investigations suggest palm geotextiles are an effective, cheap and economically-viable soil conservation method, with tremendous potential. Palm geotextiles offer enormous multi-faceted environmental and socio-economic benefits, which include environmental education and local community involvement in reclamation and environmentalimprovement programmes that reduce local community health risks.

Keywords: urban settlement, soil erosion, soil properties, deforestation.
\end{abstract}




\section{Introduction}

Water erosion can contribute to landslides, endangering life and property [1]. Inappropriate land management, including the lack of maintenance of vegetation cover, is one of the causes of gully erosion [2]. By removing vegetation cover the erosion-resisting capacity of soil becomes disturbed. The kinetic energy of raindrop splash increases, resulting in increased soil detachment. Hydraulic surface flow increases with the lack of vegetation cover, which also increases soil susceptibility to erosion, by reducing cohesion and shear strength [3].

Urban soil erosion, particularly in Brazil, is attributed to both environmental and socio-economic conditions, principally unauthorized and/or inefficient urban development and planning [4]. In that sense, the occurrence of erosive processes is generally associated with irregular population settlement, that is, those areas where there are usually no formal urban design or planning regulations instigated. For instance, in São Luís City and surrounding areas (State of Maranhão) in northeastern Brazil (Figure 1), deforestation has paved the way for accelerated urban expansion, which has promoted very severe soil erosion and, in doing so, aided gully formation [5]. These are large-scale erosion features, which can cause homes and lives to be at risk (Plate 1). Between 1997-2003, soil gully erosion was responsible for five deaths and the destruction of 350 homes in São Luís City alone.
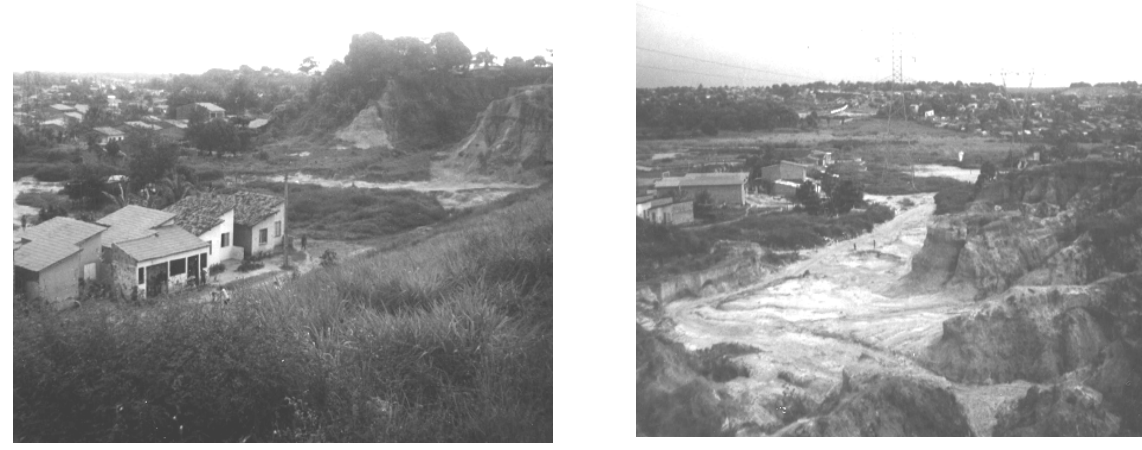

Plate 1: Soil erosion gullies bordering houses in São Luís City.

This work presents an insight into (i) the factors associated with soil erosion gully formation and (ii) the innovative approach of remediating gullies by the application of palm-mat geotextiles as a soil conservation technique and the widespread community based initiative to educate and safeguard the lives and properties of local populations in São Luís, Brazil.

\section{Soil gully erosion}

A gully (or large rill) is defined as "a channel or miniature valley cut by concentrated runoff but through which water commonly flows only during or 
immediately after heavy rains" $[6,7]$. Meanwhile, gully erosion is defined as the process whereby runoff water accumulates and often recurs in narrow channels and, over short periods, removes the soil from this narrow area to considerable depths [8]. That said, natural slope failure is mainly associated with human intervention either for urbanization or for other development activities. A small initial movement in an unstable slope can trigger further soil water movement, resulting in soil erosion and consequent landslides. The degree of stability of a given slope can vary widely depending on the conditions existing at a given time [9].

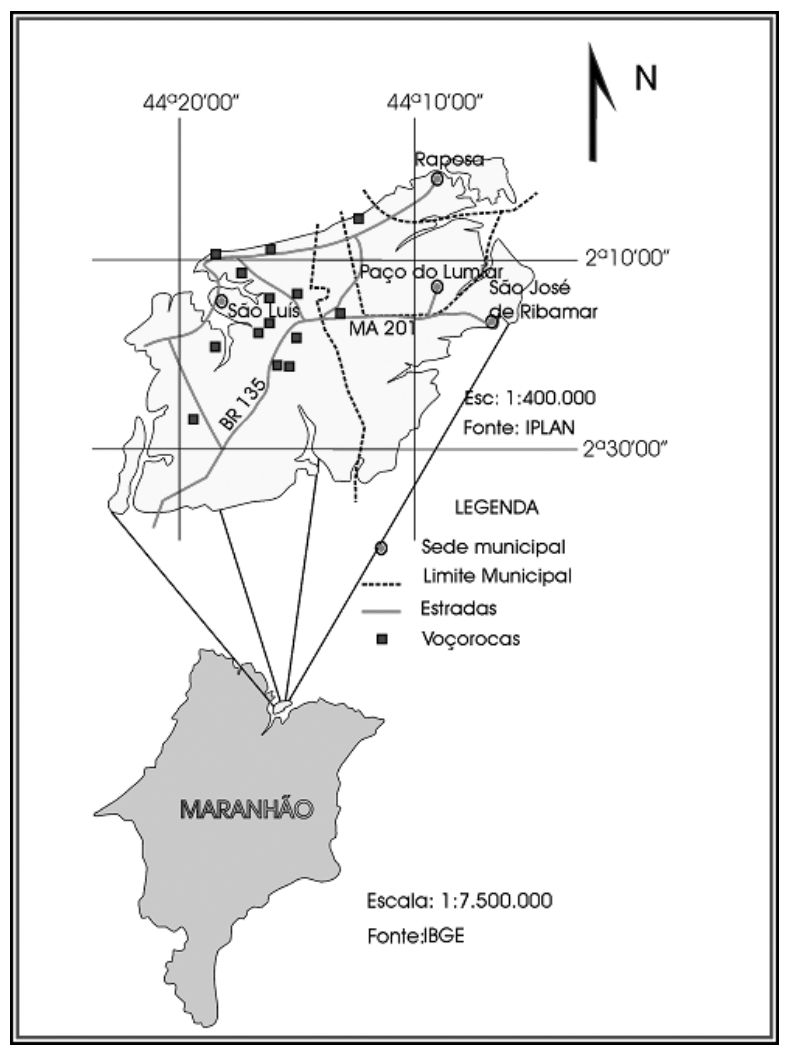

Figure 1: Location map of the research area around the City of São Luís, on the Island of Maranhão, at the north of the State of Maranhão, along the northeastern Brazil coastline. For reference: Legenda - captions; Sede municipal - Municipal centre; Limite municipal - Municipal border; Fonte: Source; Escala - scale; Estradas - Roads; Voçorocas - Gullies.

Gullies mainly form on freshly exposed soils when the vegetation cover is very sparse. At such times, concentrated runoff, generated by rainstorms, erodes the (sealed) top soil layer when the flow shear stress exceeds a critical value 
[10]. In general, rainfall intensity, catchment size, runoff coefficient, surface roughness and slope morphology collectively determine flow width. Flow discharge and surface slope together determine flow intensity. Soil moisture, soil structure and soil profile characteristics determine soil resistance to detachment and transport [7].

Poesen et al. [8] stated that once gullies develop, they often trigger other soil degradation processes, such as piping, soil fall or soil topple (driven by gravity) after tension crack development and undercutting. Furthermore, gully channels enhance the export of sediment produced on the intergully areas (sheet and rill erosion) by increasing the connectivity in the landscape, which leads to an increased risk of sediment deposition downslope. If no gully control measures are taken, gully growth rates usually decline exponentially.

Vegetation cover, because of its thinness, is often undervalued in terms of its control over landscape incision and evolution. Its resistance to erosion may be of the same order of magnitude as the underlying bedrock [8, 11]. In Brazil, deforestation, amongst others, is identified as one of the primary factors responsible for initiating gullying [12]. In that sense, the environmental landscape observed in São Luís is prone to gullying. The bedrock is very susceptible to weathering and erosion [13]. The annual rain regime is rather irregular, being marked by two different periods: a rainy one with moderate to high rain surpluses and another one with rain deficiency [5]. The soils are clay deficient, with low organic matter contents, which promotes their susceptibility to erosion. Consequently, where gullies have formed, the original vegetation cover has been felled and cleared for urban expansion, so soil erosion is common [13]. Therefore, depending on severity and timing, sudden mass movements of erodible materials within soil erosion gullies present environmental risks to both homes and the health of local communities.

\section{Management and remediation of soil erosion gullies}

In principle, gully prevention can be achieved by either preventing runoff from flowing, by increasing soil infiltrability (e.g. improving topsoil structure), or by increasing the resistance of the top layer of soil to concentrated flow erosion (e.g. soil compaction, no-tillage or establishing grassed waterways) [7]. Where possible, natural vegetation with well-developed root mats can be (re)established in disturbed concentrated flow zones affected by gully erosion. In doing so, soil loss and sediment production will be reduced [8]. Natural vegetation for sustainable erosion control and slope protection is a proven choice of soil conservation [9]. Those constructed from organic materials are highly effective [14].

Several slope protection/remediation techniques are currently employed to stabilize slopes. Application of geotextiles is especially beneficial for complex engineering problems, as temporary application of geotextiles allows sufficient time for plant communities to grow and stabilize slopes by intertwining of roots, which maximizes seepage of runoff into soil by intercepting rainfall and retarding runoff velocity [15]. Furthermore, if constructed from indigenous 
materials, such as palm-leaves, geotextiles can be effective, affordable and compatible with sustainable land management strategies. The ability of natural fibres to absorb water and degrade into the soil with time are prime properties, which offer an improvement over synthetic geotextiles for slope stability applications.

\section{Application of palm-leaf geotextiles}

\subsection{Environmental and socio-economic rewards of palm-mat geotextiles}

Preliminary investigations suggest palm-mat geotextiles could be an effective and cheap soil conservation method, with enormous global potential. The strategic impact of palm-leaf geotextiles involves the promotion of sustainable and environmentally friendly palm-agriculture, which will discourage deforestation, promote both reforestation and agroforestry and offer a potentially profitable technique to augment the income of financially deprived communities. Thus, construction of palm geotextiles could develop into a rural, labourintensive industry, particularly encouraging the employment of sociallydisadvantaged groups, such as women, disabled and elderly people (i.e. handwork performed sitting down). Moreover, export of completed palm geotextiles will earn hard currency and promote development, based on the principles of fair trade.

Palm-leaf geotextiles can improve the socio-economic foundation for sustainable development in developing countries. Potential benefits include poverty alleviation, engagement of disadvantaged groups as stakeholders, employment for disadvantaged groups, SME development, export of geotextiles earning hard currency, environmental education and local community involvement in reclamation and environmental-improvement programmes. Education programmes are necessary to actively inform the public of the importance of soil as an essential resource. These schemes should particularly encourage 'land literacy' among participants so that society recognizes broader benefits of effective soil conservation, such as its potential contribution to habitat creation, biodiversity and carbon sequestration [16].

\subsection{Geotextile palm-mat manufacture}

A small workshop was established in Brazil, to harvest and manufacture palm mats (Plate 2). Fronds were cut and sun-dried over several weeks. The thick central spines, which give the leaf their fan-like appearance, were stripped and the vegetation cut into lengths ranging from 1-1.5 m length and $2 \mathrm{~cm}$ width. These were then soaked in water to make the material pliable and then using a $2,500 \mathrm{~cm}^{2}$ wooden template, woven into $50 \times 50 \mathrm{~cm}\left(2,500 \mathrm{~cm}^{2}\right)$ squares, where the outer edge of the mat was sewn using fibre from the leaf waste. Strips were then woven into a grid pattern, vertically and horizontally, using a slipknot at 5 $\mathrm{cm}$ intervals. Then every strip was wrapped around, working from one edge to the other, using the prepared material. 
(a)

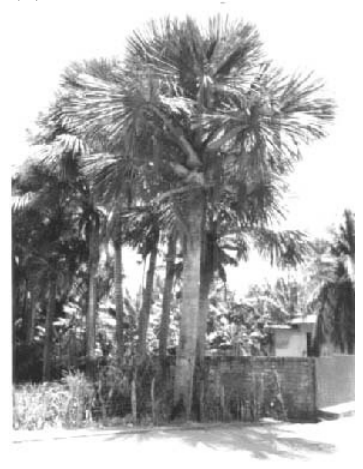

(b)

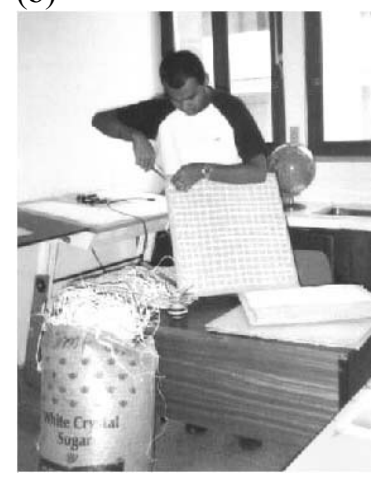

(c)

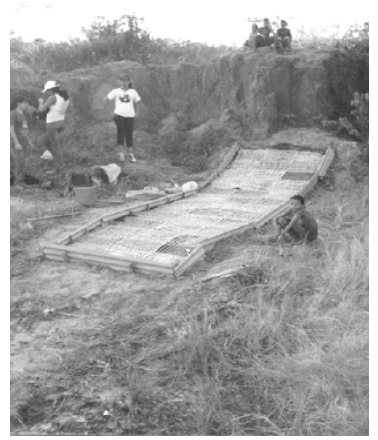

Plate 2: (a) Brazilian Buriti palms; (b) Palm-mat geotextile production and (c) A field erosion test plot covered with palm-mats.

\subsection{Field application of palm-mat geotextiles: U.K. pilot study results}

A pilot study is in progress, evaluating palm-mat effects on runoff and erosion rates from established runoff plots, based at the University of Wolverhampton's

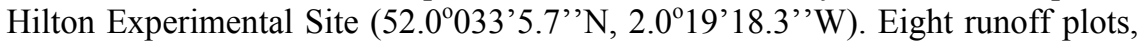
situated on a $15^{\circ}$ south-west facing slope, numbered D1-D8 and measuring $10 \mathrm{x}$ $1 \mathrm{~m}$, are used for the field study.

The runoff investigation consisted of 35 observations over 98 weeks, with the first six observations used as a calibration period (showing reasonable bare soil comparability: data not presented). Total plot data for the period 25/03/200209/02/2004 (precipitation total $1118.4 \mathrm{~mm}$ ) is shown in Table 1. Runoff volumes from both grassed plots were similar. In contrast, runoff volume from the buffer zone plots and geotextile plots show noticeable differences. Comparatively, runoff from the geotextile covered plots was higher than the bare plots by a mean of $121.2 \%$, while runoff from the buffer zone plots was lower than the bare plots by a mean of $60.5 \%$. Total runoff as a $\%$ of the precipitation for the bare plots $(0.59 \%)$ was notably higher than both the grassed $(0.44 \%)$ and buffer $(0.36 \%)$ treatments, but not the geotextile-covered plots $(0.71 \%)$.

Erosion from the treated plots was noticeably lower than from the bare plots during the same period. Sediment yields from the buffer zone plots were similar. In contrast, there are notable differences in sediment yields from the bare, grassed, geotextile-covered and buffer zone plots. Hence, mean total soil loss equates to $0.81 \mathrm{t} \mathrm{ha}^{-1}$ from the bare plots, $0.30 \mathrm{t} \mathrm{ha}^{-1}$ from both the covered plots, $0.29 \mathrm{t} \mathrm{ha}^{-1}$ from the buffer zone plots and $0.12 \mathrm{t} \mathrm{ha}^{-1}$ from the grass plots. Since erosion from buffer strip plots approximately equals those from mat-covered plots, this indicates buffer strips are very effective in reducing erosion.

Pilot study data suggest palm-mat geotextiles are effective in reducing runoff when used as a buffer zone. However, it remains to be shown if the mats can reduce runoff compared to bare soil. While these results were obtained in a 
humid temperate climate, further experiments will verify their applicability in the humid tropics of Brazil.

Table 1: Runoff and erosion plot data at the Hilton Experimental Site. Note using random selection, plots D2 and D8 were completely covered with palm-mats, D4 and D5 had $1 \mathrm{~m}$ buffer zones of palm-mats at the plot lower end, D1 and D6 are the bare soil (control) plots and D3 and D7 are grassed plots.

\begin{tabular}{|l|l|l|l|l|l|l|}
\hline Plot & \multicolumn{2}{|l|}{ Total runoff $(\mathrm{l})$} & \multicolumn{3}{l|}{ Total sediment yield $(\mathrm{g})$} \\
\hline$(\mathrm{n}=29)$ & Total & Mean & S.D. & Total & Mean & S.D. \\
\hline D1 & 24.5 & 0.8 & 0.9 & 71.9 & 2.6 & 3.4 \\
\hline D2 & 22.8 & 0.8 & 1.0 & 41.9 & 1.5 & 1.8 \\
\hline D3 & 20.9 & 0.7 & 0.9 & 15.0 & 0.5 & 0.4 \\
\hline D4 & 12.8 & 0.4 & 0.7 & 29.4 & 1.0 & 1.4 \\
\hline D5 & 27.1 & 0.9 & 0.7 & 30.2 & 1.1 & 1.2 \\
\hline D6 & 41.1 & 1.4 & 1.3 & 89.6 & 3.2 & 5.4 \\
\hline D7 & 27.9 & 1.0 & 1.1 & 9.4 & 0.3 & 0.4 \\
\hline D8 & 56.6 & 2.0 & 1.9 & 15.1 & 0.5 & 0.4 \\
\hline
\end{tabular}

\section{Ongoing and proposed further work}

A research team, based in Europe, South America, Africa and South-East Asia, funded by the EU for three-years (Project 'BORASSUS': Contract Number 510745), has recently commenced the first complete scientific and socioeconomic evaluation of the potential of palm-leaf geotextiles. Full geotechnical evaluations of these geotextiles are an integral part of the work. Therefore, as part of the established information dissemination strategy, the team will publish manufacturing and production protocols and standards. These will be broadly disseminated and thus available for SMEs to adopt and adapt. These standards will contribute to the global production of high-quality palm-mat geotextiles suitable for multiple and complex applications [16].

\subsection{South American (Brazilian) research work-package}

Based on field studies at an established research site in São Luís, the workpackage aims to: (i) understand where, how and at what rates gully erosion occurs; (ii) measure and assess urban gully erosion and identify the primary controlling factors; (iii) compare areas under palm mats protection with areas with no protection against erosion; (iv) examine the relation between gully erosion and environmental and socio-economic factors, and recuperate as many gullies as reasonably possible; (v) educate and assist local authorities and nongovernmental organizations, in terms of alternative geotextile technology to recuperate urban gullies and (vi) engage with communities affected by these potentially life-threatening features, by initiating an environmental-awareness programme to inform and educate them on gully erosion and control. 


\section{Conclusions}

Environmental and socio-economic conditions have attributed to urban soil erosion in Brazil, which has lead to the initiation and formation of gullies. The severity and sudden impact of these features has caused the loss of lives and homes. As part of an international research project (Borassus, funded by the EU for 3-years), a field site (São Luís) in NE Brazil is evaluating palm-leaf geotextile mats as a possible remediation technology.

Preliminary results indicate that geotextiles constructed from palm-leaves have potential as a biotechnical soil conservation method and effectively reduced soil erosion. If harvested correctly, palm leaves are highly sustainable and readily available in most semi-arid and sub-humid bioclimatic regions. They are biodegradable, providing organic content matter to stabilize the soil and their permeability makes them suitable for use with cohesive soils. There are no highenergy production procedures in the manufacturing process and, when used in their natural environment, they may provide a cost-effective method of conserving soil in developing countries, where land remediation techniques are scaled to low levels of disposable income. That said, ultimately, and more importantly, they might even save lives and properties of Brazilian communities

\section{Acknowledgements}

This work is dedicated to the memory of Dr Kathy Davies, to whom we acknowledge as the initiator and inspiration for palm-leaf geotextile research. All authors would like to gratefully acknowledge and thank the technical and support staff at each university.

\section{References}

[1] Hudson, N.W., A study of the reasons for success and failures of soil conservation projects. FAO Soils Bulletin No. 64. Soil Resources Management and Conservation Service, FAO Land and Water Development Division, Silsoe Agricultural Associates, Bedford, U.K., 2001.

[2] Casal, J., Lopez. J.J. \& Giraldez, J.V., Ephemeral gully erosion in southern Navarra (Spain). Catena, 36, pp. 65-84, 1999.

[3] Rickson, J., The best is yet to come. Ground Engineering, 34, pp. 13-14, 2001.

[4] Sobreira, F.G., A ocupação desordenada nas encostas de Ouro Preto, $M G$. Revista Escola de Minas, 42, pp. 12-16, 1989.

[5] Mendonca, J.K.S., Relatório Final: Diagnóstico da erosão urbana no município de São Luis-MA. Relatório 03-2002/02. São Luis: UFMA, 2003.

[6] Soil Conservation Society of America, Resource Conservation Glossary. Soil Conservation Society of America, Ankeny (USA), 1982. 
[7] Poesen, J. \& Govers, G., Gully erosion in the loam belt of Belgium: typology and control measures. In: Soil Erosion on Agricultural Land, Eds. J. Boardman, I.D.L. Foster, \& J.A. Dearing, John Wiley \& Sons: Chichester (UK), pp. 513-530, 1990.

[8] Poesen, J., Nachtergaele, J., Verstraeten, G. \& Valentin, C., Gully erosion and environmental change: importance and research needs. Catena, 50, pp. 91-133, 2003.

[9] Lekha, K.R., Field instrumentation and monitoring of soil erosion in coir geotextiles stabilised slopes - A case study. Geotextiles \& Geomembranes, 22, pp. 399-413, 2004.

[10] Rauws, G. \& Govers, G., Hydraulic and soil mechanical aspects of rill generation on agricultural soils. Journal of Soil Science, 39, pp. 111-124, 1988.

[11] Howard, A.D., Simulation of gully erosion and bistable landforms. In: Proceedings of the Conference on Management of Landscapes Disturbed by Channel Incision, Eds. S.S.Y. Wang, E.J. Langendoen \& F.D. Shields, Center for Computational Hydroscience \& Engineering, The University of Mississippi, Oxford MS, pp. 516-521, 1997.

[12] Guerra, A.J.T., Processos erosivos nas encostas. In: Geomorfologia: exercícios, técnicas e aplicações, Eds. Guerra, A.J.T. \& Cunha, S.B., Bertrand: Rio de Janeiro (Brazil), pp. 139-155, 1996.

[13] Guerra, A.J.T.; Mendonca, J.K.S.; Marcelo, R. \& Alves, I.S., Gully erosion monitoring in São Luis city - Maranhão State - Brazil. In: Gully Erosion Under Global Change. Eds. Li, Y.; Poesen, J. \& Valentin, C., Chengdu, China: Sichuan Science and Technology, 2004.

[14] Ogbobe, O., Essien, K.S. \& Adebayo, A., A study of biodegradable geotextiles used for erosion control. Geosynthetics International, 5, pp. 545-553, 1998.

[15] Ahn, T.B., Cho, S.D. \& Yang, S.C., Stabilization of soil slope using geosynthetic mulching mat. Geotextiles \& Geomembranes, 20, 135-146, 2002.

[16] Booth, C.A., Davies, K. \& Fullen, M.A., Environmental and socioeconomic contributions of palm-leaf geotextiles to sustainable development and soil conservation. In: Ecosystems and Sustainable Development $V$, Eds. E. Tiezzi, C.A. Brebbia, S.E. Jorgensen \& D. Almorza Gomar, WIT Press: Southampton (UK), pp. 649-658, 2005. 